\title{
ARISTOTELES
}

\section{DE ANIMA,}

DE SENSU, DE MEMORIA, DE SOMNO SIMILIQUE ARGUMENTO.

EX RECENSIONE

\section{IMMANUELIS BEKKERI.}

\author{
BEROLIN I \\ TY P I S A C D E M I C I S.
}

$=$

I MPENSIS GE. REIMERI

^. MDCCCXXIX. 
